\title{
GENOTOXICITY EVALUATION OF CISSUS LATIFOLIA LAM. AND ITS GENOPROTECTIVE EFFECT ON OXIDATIVE DAMAGE INDUCED BY HYDROGEN PEROXIDE
}

\author{
RUBEENA M*, JOHN E THOPPIL \\ Department of Botany, Cell and Molecular Biology Division, University of Calicut, Malappuram, Kerala, India. Email: rubs131@gmail.com \\ Received: 09 March 2020, Revised and Accepted: 18 April 2020
}

\begin{abstract}
Objective: This study focused on the genotoxic efficacy of higher concentrations of methanolic extract of Cissus latifolia Lam. and its genoprotective role at lower concentrations against the induced cytogenetic aberrations by $2 \%$ hydrogen peroxide $\left[\mathrm{H}_{2} \mathrm{O}_{2}\right]$ on the Allium cepa plant model.

Methods: Cytotoxic and genoprotective potential of the plant extract were analyzed using $A$. cepa assay. The treatment modes that were designed for antigenotoxicity screening were pre-treatment, post-treatment, and concurrent treatment.

Results: Results revealed the toxic effect of extract of $C$. latifolia which induced major chromosomal abnormalities, namely, nuclear lesions, chromosome vagrants, stickiness, bridges, and chromosome breaks. These aberrations were found to be unaltered and showed the potent clastogenic nature of plant extract. As concentrations of plant extract and exposure time increase, the frequency of occurrence of cytogenetic aberrations was also detected to be more. Further, the potential genotoxicity of plant measured in terms of mitotic index reduction also confirms its significant role in inducing mutagenicity. The genoprotective efficacy of extract was identified as its ability to inhibit and reverse the aberrations caused by $\mathrm{H}_{2} \mathrm{O}_{2}$ at lower concentrations of plant extract
\end{abstract}

Conclusions: Dose-dependent data highlight the cytotoxic and genoprotective effect of $C$. latifolia on the $A$. cepa model. These findings will help to exploit the plant as an anticancer drug and explore other wide arrays of therapeutic activities of $C$. latifolia.

Keywords: Cissus latifolia, Genotoxicity, Genoprotection, Hydrogen peroxide, Inhibitory activity.

(C) 2020 The Authors. Published by Innovare Academic Sciences Pvt Ltd. This is an open access article under the CC BY license (http://creativecommons. org/licenses/by/4. 0/) DOI: http://dx.doi.org/10.22159/ajpcr.2020.v13i7.37382

\section{INTRODUCTION}

Plants have been used as medicines for various ailments since ancient times. Although synthetic medicines are dominated and continue to progress, certain diseases are forcing the need of returning to the natural compounds for complete relief. Exploring the genotoxicity of herbal medicines is a greatly concerned field of pharmacology as the scientific community is targeted on making effective drugs from medicinal plants. Besides therapeutic potential, some medicinal plants have reported being poisonous and teratogenic due to the presence of toxic compounds $[1,2]$. Thus, it is inevitable to screen the medicinal plant toxicity levels to validate its safety and efficacy for effective drug designing [3]. Cytogenetic screenings are the basis of identifying the harmful materials at their divergent levels of quantity and exposure times [4,5]. Allium cepa documented as an excellent plant model species to screen the same [6]. Several plant species tested and designed as genetic tools for environmental pollutant screening and monitoring $[7,8]$.

As plants are used as medicinal and for commercial purposes, the assessment and screening of the harmful effect of environmental pollutants on plant community are indispensable to validate its ecological and genetic influence [9]. When chemicals are released into our environment, it will disrupt the balance of our ecosystems. Hydrogen peroxide $\left(\mathrm{H}_{2} \mathrm{O}_{2}\right)$ is considered as the potent mutagen which can induce damages to DNA [10] and cause oxidative-stress by generating reactive oxygen species (ROS) in cells. Plants are blessed with their defensive system of antioxidants, either enzymatic or non-enzymatic, to compress oxidative stress [11]. European Commission, (2003) found that $\mathrm{H}_{2} \mathrm{O}_{2}$ is an endogenous product of oxygen reduction in the aerobic cell and passes readily across biological membranes [12]. There is no proven antidote for $\mathrm{H}_{2} \mathrm{O}_{2}$ poisoning, even though it can be treated.

Cissus latifolia Lam. is a species found in moist deciduous forests and the Western Ghats and belongs to the grape family, Vitaceae. It is distributed in
Peninsular India and Sri Lanka. It is a large climbing shrub having a thick glaucous stem, ovate to cordate leaves having forked tendrils. The plant is used in the treatment of weak bones, bone fractures, cancer, scurvy, peptic ulcer disease, hemorrhoids, malaria, pain, and asthma. This is an underexplored medicinal plant for its therapeutic values. Since its genotoxicity studies have not been reported yet, the purpose of the present research is to explore the clastogenic potential and genoprotective effect of methanolic plant extract. The study attempts to estimate the efficacy of the plant being used as an anticancer and as well as genoprotective agent.

\section{MATERIALS AND METHODS}

\section{Plant material}

C. latifolia Lam. was collected from Malappuram district of Kerala (coordinates $11^{\circ} 02^{\prime} 28^{\prime \prime} \mathrm{N} 76^{\circ} 04^{\prime} 59^{\prime \prime} \mathrm{E}$ ), taxonomic identification was done, and the voucher specimen was stored (CALI NO: 123762) in the Calicut University Herbarium (CALI).

\section{Plant model and chemicals}

Healthy Onion bulbs (A. cepa $\mathrm{L} ., 2 \mathrm{n}=16$ ), free from agricultural pesticides and growth inhibitors (procured from TNAU (Tamil Nadu Agriculture University) Tamil Nadu), were used for the present study. $\mathrm{H}_{2} \mathrm{O}_{2}$ (CAS no.: 7722-84-1) was obtained from Merck Pvt. Ltd. (Mumbai, India).

\section{Preparation of the methanolic extract and control}

Finely powdered plant material was subjected to Soxhlet extraction using methanol for $6 \mathrm{~h}$. After evaporating the solvent, $1 \mathrm{~g}$ of the dried extract was weighed and a stock solution of $1 \%$ was prepared for making the different concentrations of plant extract for the treatment. Deionized water was used as negative control and $(0.01 \%)$ organophosphorus pesticide methyl parathion as the positive control.

\section{Genotoxicity assay}

Uniformly sized bulbs of A. cepa were planted in sterilized sandy soil without any fertilizers to avoid the chance of cellular alterations. 
Healthy roots $(1-2 \mathrm{~cm})$ were collected at the peak mitotic period. It was then washed in distilled water and treated in different concentrations of the plant extract $(0.001,0.005,0.01,0.05$, and $0.1 \%)$. Root tips kept in the samples at different time intervals of $1 / 2 \mathrm{~h}, 1 \mathrm{~h}, 3 \mathrm{~h}$, and $24 \mathrm{~h}$ were cut and immediately fixed in modified Carnoy's fluid for 1 $\mathrm{h}$ after washing with distilled water. Mitotic squash preparation was done with the help of improved techniques [13]. Hydrolysis with $1 \mathrm{~N} \mathrm{HCl}$ and staining with $2 \%$ acetocarmine was carried out. All the slides were scanned and tabulated, and photomicrographs were taken using 40X LEICADM6 B System Microscope and fluorescent imaging Camera LEICA DFC 450C for genotoxicity evaluation. Mitotic index and abnormality percentage were calculated by counting the mitotic cells and aberrant cells, respectively, out of the total cells observed and values were expressed as mean \pm SE from at least three independent experiments:

$$
\begin{aligned}
& \text { Mitotic index }(\%)=\frac{\text { Number of dividing cells }}{\text { Total number of cells }} \times 100 \\
& \text { Abnormality }(\%)=\frac{\text { Number of aberrated cells }}{\text { Total number of cells }} \times 100
\end{aligned}
$$

\section{Evaluation of genoprotective effect}

Three modes of treatments were conducted for screening antigenotoxicity studies [14]. Bulbs of A. cepa were allowed to grow an average root length $(0.5-1 \mathrm{~cm})$ by keeping in glass vials containing distilled water.

\section{Pre-treatment}

Germinated bulbs with roots were first tested by keeping in different concentrations $(0.002 \%, 0.004 \%, 0.006 \%$, and $0.008 \%)$ of extracts for $24 \mathrm{~h}$ followed by treatment with $\mathrm{H}_{2} \mathrm{O}_{2}(2 \%)$ for $1 \mathrm{~h}$.

\section{Post-treatment}

The onion bulbs with roots first treated with $2 \% \mathrm{H}_{2} \mathrm{O}_{2}$ and then allowed to stay in plant extract concentrations for $24 \mathrm{~h}$

\section{Concurrent treatment}

Root tips were dipped simultaneously in solutions containing $\mathrm{H}_{2} \mathrm{O}_{2}$ (2\%) and extract concentrations of $1 \mathrm{~h}$.

About $2 \%$ of $\mathrm{H}_{2} \mathrm{O}_{2}$ and distilled water served as positive and negative controls, respectively. Once all the treatments completed, all bulbs were washed, and root tips were cut and preceded further analysis for making slides for the study. Acetocarmine was used for the staining process.

Inhibitory activity (\%) was calculated by the formula:

$$
\text { Inhibitory activity }(\%)=\frac{\mathrm{A}-\mathrm{B}}{\mathrm{A}-\mathrm{C}} \times 100
$$

Where $\mathrm{A}=$ Number of aberrant cells induced by the positive control $B=$ Number of aberrant cells induced by different modes of treatment $\mathrm{C}=$ Number of aberrant cells induced by negative control

Growth and morphology (shape and color) of roots were recorded after $48 \mathrm{~h}$.

\section{Statistical analysis}

SPSS version 10 was used for statistical analyses. Data obtained were then subjected to DMRT and one-way ANOVA to confirm the variability of the data and validity of results. All results were expressed as mean $\pm \mathrm{SE}$, and differences between corresponding controls and exposure treatments were considered statistically significant at $p<0.05$. The linear relationship between dose and the effect of aqueous extract in terms of inhibition percentage was obtained by simple regression and correlation analysis.

\section{RESULTS}

\section{Genotoxicity evaluation}

The evaluation of the genotoxicity of $C$. latifolia was monitored by the $A$. cepa model system. The treatment in the four different concentrations $(0.005,0.01,0.05$, and $0.1 \%)$ of the methanolic extract at different time intervals $(1 / 2,1,3$, and $24 \mathrm{~h})$ distinctly revealed the genotoxic potential of the plant. A dose-dependent decrease in the mitotic activity of the cells manifested the cytotoxic activity of the extract. A very low mitotic activity was detected in the treatment with the highest concentration of the extract $(0.1 \%)$. It was found to be a $\sim 50 \%$ decrease in the cell division when compared with the negative control. The data shown in Fig. 3 represented the significant mitotic index reduction when treated with the extract of $C$. latifolia. Despite concentration tested, time also played an important role in evaluating genotoxicity and mitotic index reduction. The root tips exposed to the plant extract for an extended time period of $24 \mathrm{~h}$ showed a severe decline in the mitotic activity (Fig. 3). The highest mitotic activity (82.7\%) in cells was reported in the extract with lowest concentration (0.005\%) exposed to a minimum period of $1 / 2$

Table 1: Genoprotective activity of Cissus latifolia on Allium cepa root tip meristem treated with $2 \% \mathrm{H}_{2} \mathrm{O}_{2}$

\begin{tabular}{llll}
\hline Concentration (\%) & $\begin{array}{l}\text { Chromosomal aberration } \\
\text { by } \mathbf{H}_{2} \mathbf{O}_{2}(\%) \pm \text { SE }\end{array}$ & $\begin{array}{l}\text { Percentage of inhibition } \\
\text { by plant extract } \pm \text { SE }\end{array}$ & Root length \pm SE (cm) \\
\hline C-- & $5.05 \pm 2.42^{\mathrm{a}}$ & $0.000 \pm 0.000^{\mathrm{a}}$ & $1.56 \pm 0.14^{\mathrm{g}}$ \\
C++ & $95.17 \pm 0.54^{\mathrm{i}}$ & $0.000 \pm 0.000^{\mathrm{a}}$ & $0.44 \pm 0.03^{\mathrm{a}}$ \\
Pre-treatment & & & $1.35 \pm 0.076^{\mathrm{f}}$ \\
0.002 & $87.54 \pm 1.42^{\mathrm{h}}$ & $30.11 \pm 2.12^{\mathrm{d}}$ & $1.1 \pm 0.05^{\mathrm{e}}$ \\
0.004 & $84.03 \pm 1.33^{\mathrm{g}, \mathrm{h}}$ & $22.08 \pm 1.94^{\mathrm{c}}$ & $0.92 \pm 0.03^{\mathrm{d}}$ \\
0.006 & $84.17 \pm 0.50^{\mathrm{g}}$ & $13.94 \pm 1.78^{\mathrm{b}}$ & $0.93 \pm 0.03^{\mathrm{d}}$ \\
0.008 & $82.65 \pm 0.66^{\mathrm{g}}$ & $45.45 \pm 1.9^{\mathrm{e}}$ & \\
Post-treatment & & & $0.38 \pm 0.04^{\mathrm{a}}$ \\
0.002 & $65.69 \pm 2.28^{\mathrm{f}}$ & $51.01 \pm 1.27^{\mathrm{f}}$ & $0.64 \pm 0.02^{\mathrm{b}}$ \\
0.004 & $50.73 \pm 2.58^{\mathrm{d}}$ & $67.22 \pm 3.40^{\mathrm{g}}$ & $0.80 \pm 0.02^{\mathrm{d}}$ \\
0.006 & $49.28 \pm 0.30^{\mathrm{d}}$ & $55.10 \pm 0.95^{\mathrm{f}}$ & $0.95 \pm 0.01^{\mathrm{e}}$ \\
0.008 & $32.57 \pm 0.24^{\mathrm{b}}$ & $67.12 \pm 0.71^{\mathrm{g}}$ & \\
Simultane & $47.48 \pm 1.90^{\mathrm{e}}$ & $0.71 \pm 0.01^{\mathrm{bc}}$ \\
0.002 & & $46.43 \pm 2.95^{\mathrm{e}}$ & $1.09 \pm 0.05^{\mathrm{e}}$ \\
0.004 & $51.02 \pm 1.94^{\mathrm{d}}$ & $62.22 \pm 2.11^{\mathrm{g}}$ & $1.38 \pm 0.01^{\mathrm{f}}$ \\
0.006 & $58.99 \pm 1.58^{\mathrm{e}}$ & $70.85 \pm 2.30^{\mathrm{h}}$ & $1.65 \pm 0.02^{\mathrm{g}}$ \\
\hline
\end{tabular}

C--: Negative control, C++: Positive control. Means with the same superscript letter do not differ statistically at the level of 0.05 ( $\mathrm{p}<0.05$; DMRT test) 


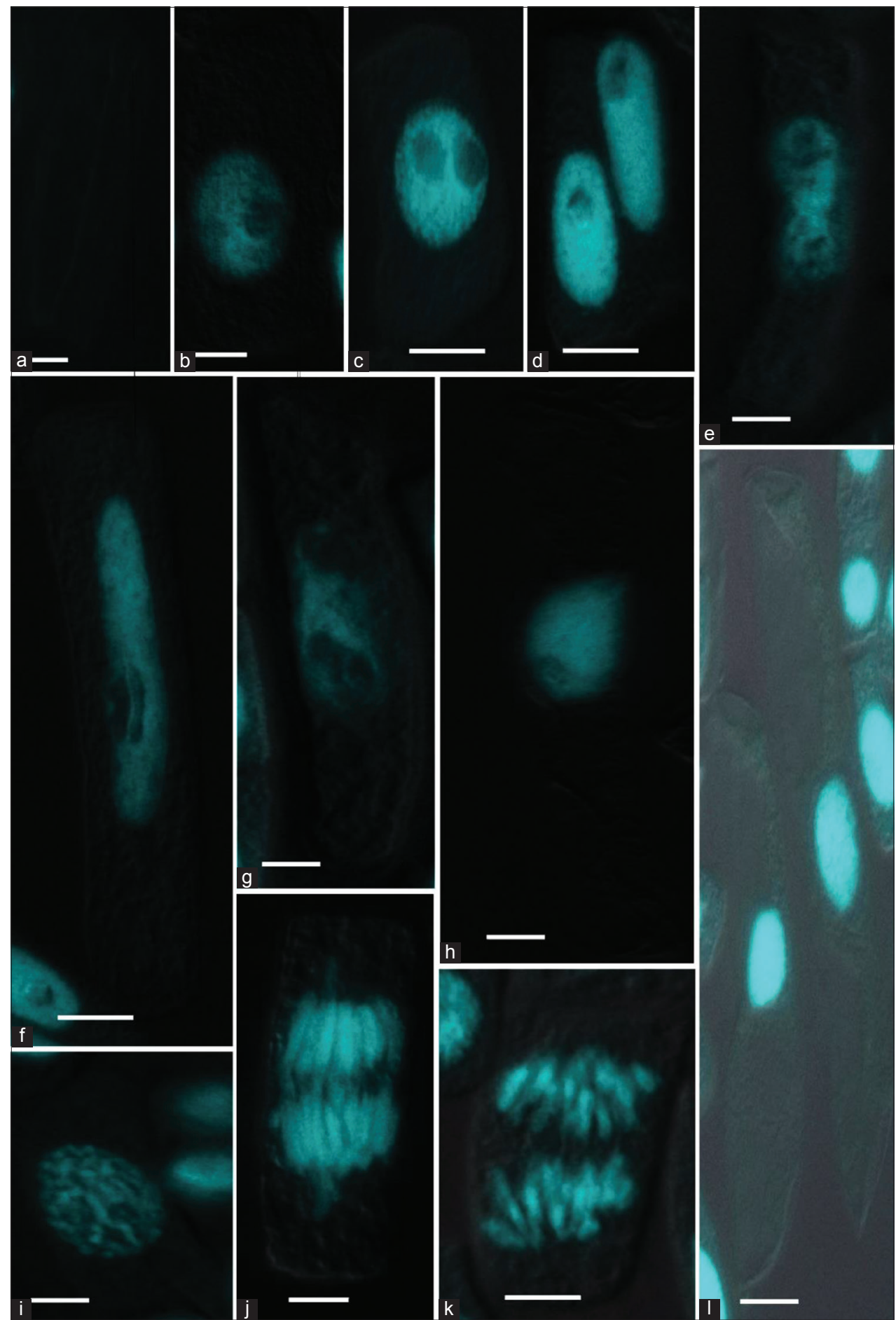

Fig. 1: Clastogenic aberrations in treated Allium cepa root tip cells: (a) Enucleated giant cell, (b) Single nuclear lesion, (c) double nuclear lesions, (d) diagonal cytokinesis with nuclear lesions, (e) nuclear disintegration, (f) strap cell with strap nucleus showing lesion,

(g) nuclear erosion, (h) nuclear peaks and cellular shrinkage in a giant cell, (i) pulverized chromatin at prophase, (j) chromosome bridges at anaphase, (k) sticky anaphase, (l) giant cells showing cytoplasmic vacuolation

$\mathrm{h}$ and the least mitotic index (37.2\%) was recorded in the extract with a higher concentration $(0.1 \%)$ at prolonged exposure to $24 \mathrm{~h}$. All the concentrations of plant extract used to put forth the significant effect on the mitotic index showing a positive correlation with the exposure time. And also, mitotic index reduction and increased plant extract concentrations were documented as positively correlated (Table 1).

The chromosomal aberrations observed during the studies undoubtedly verified the genotoxic potential of C. latifolia (Figs. 1 and 2). Very interestingly, the dose-dependent increase in the percentage of aberrations scrutinized was also convinced by the cytotoxic effect of the extract (Fig. 4). The chromosomal aberrations were classified as clastogenic and non-clastogenic aberrations. The clastogenic aberrations detected were lesions, nuclear erosion, nuclear extrusion, nuclear peak, pulverized chromatin, chromosome fragment, chromosome bridges, ring chromosome, coagulated chromatin, giant cells, etc. The most frequent abnormalities detected such as stickiness, chromosome vagrants, micronucleus, and anaphase bridges were may be the consequence 

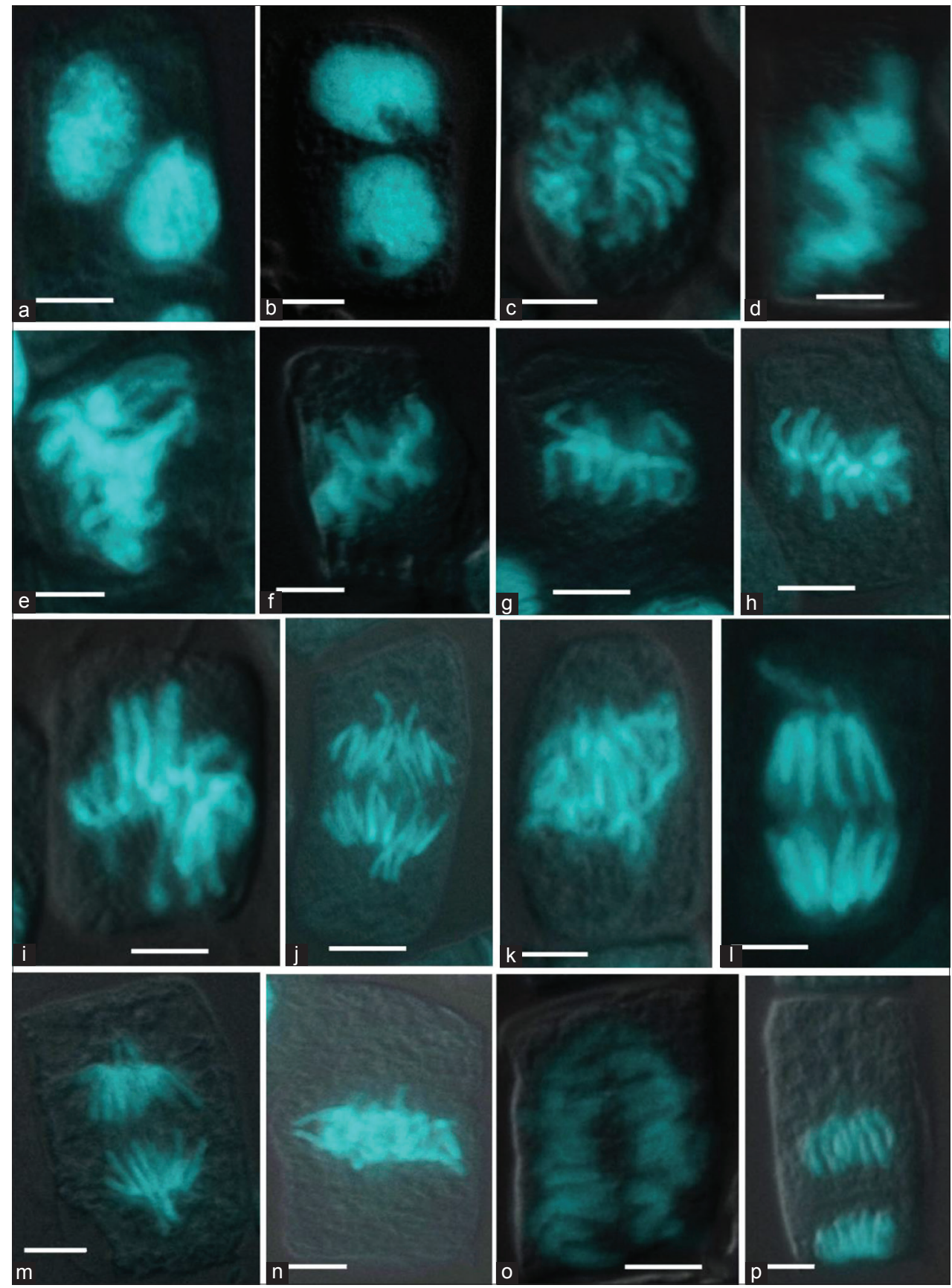

Fig. 2: Non-clastogenic aberrations in treated Allium cepa root tip cells: (a) Binucleate cell, (b) binucleate cell showing nuclear lesion and erosion, (c) ball metaphase with fragments, (d) diagonal sticky metaphase, (e) misorientation at metaphase, (f) diagonal metaphase with a fragment, (g) vagrants at metaphase, (h-i) tropokinesis, (j) early movement at anaphase, (k) diagonal stathmoanaphase, (l) Vagrant at anaphase, (m) stellate anaphase, (n) stathmoanaphase, (o) equatorial separation at anaphase, (p) shift in MTOC

of chromatin failure or spindle dysfunction. The progressive decline of dividing cells observed at different concentrations of plant extracts suggested mitodepressive effect extract on the cell division, as reported by Reshmi and Thoppil (2019) [15]. These findings revealed the selected extract concentrations of C. latifolia were inhibitory, clastogenic, and mitodepressive on cell division which connected the results of Akintonwa et al. [16]. Plant extract in higher concentrations also imposed significant membrane damages to root tips.

\section{Evaluation of genoprotective effect}

The present work also explored the genoprotective efficacy of $C$. latifolia against the toxic effect of oxidant $\mathrm{H}_{2} \mathrm{O}_{2}$. The results obtained during the screening showed the potential of the plant to withstand the oxidative damage rendered by $\mathrm{H}_{2} \mathrm{O}_{2}$ (Fig. 5). Of the three modes of treatments, only simultaneous and post-treatment showed the modulating efficacy of the extract to revert the aberrations caused due to oxidative stress. Cellular signaling mechanisms are also disrupted by oxidative stress. Cellular components, including DNA, proteins, and lipids, are damaged by free radicals and peroxides generated in response to the change in the redox potential of the cell. DNA damages by oxidative stress include base damages and strand breaks. Base damage is indirectly induced by $\mathrm{O}_{2}{ }^{-}$(superoxide radical), $\mathrm{OH}$ (hydroxyl radical), and $\mathrm{H}_{2} \mathrm{O}_{2}$. The effect of C. latifolia on the oxidative damage induced by $\mathrm{H}_{2} \mathrm{O}_{2}$ is given in Table 1 . The influence of extract on pre, simultaneous, and post-treatment can be distinguished clearly from Table 1 . It was evident that in the pre-treatment, the plant extract did not express any significant response against the oxidant treated. The percentage of inhibition of total aberrant cells in this mode of treatment is very low, ranging from 


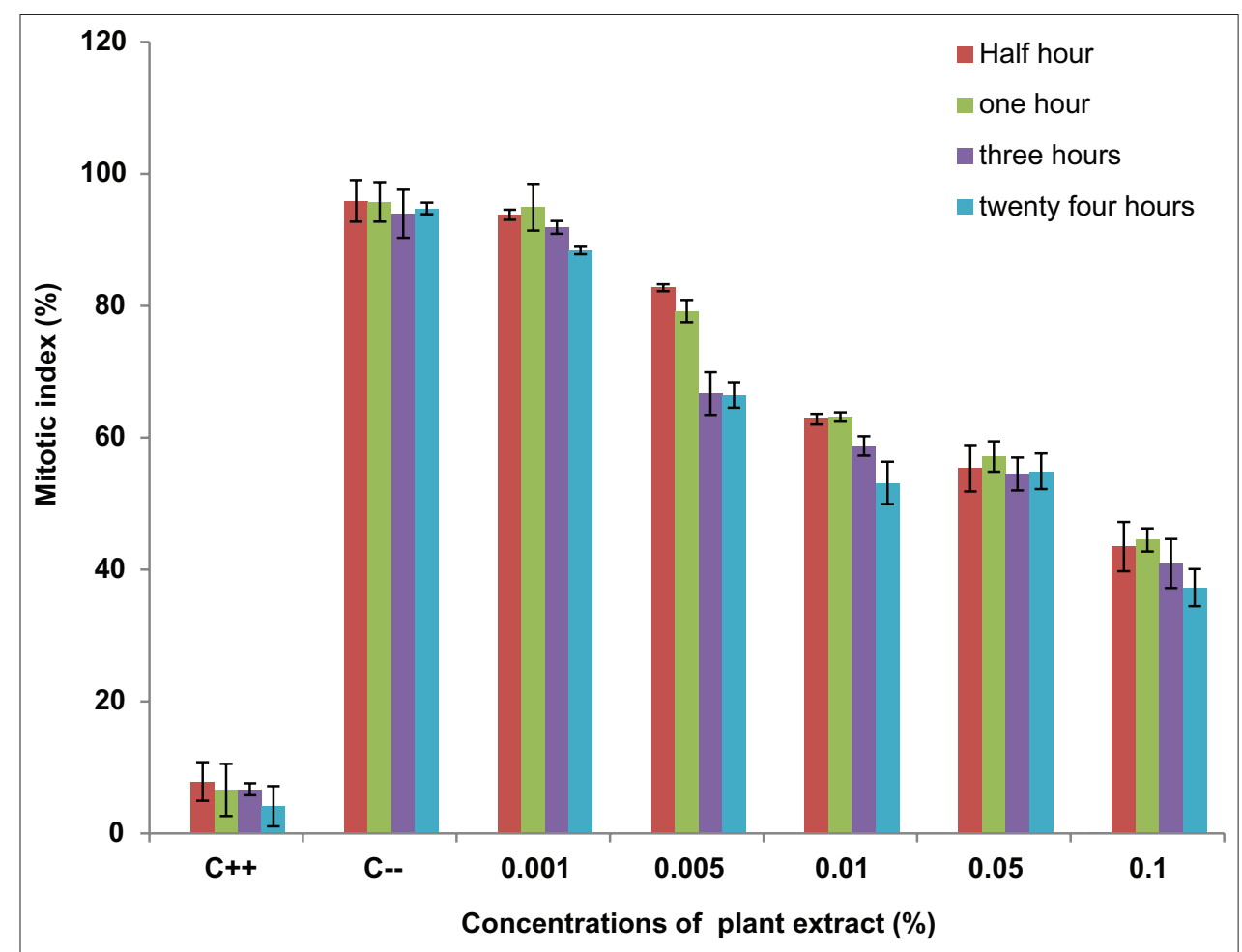

Fig. 3: Dose-dependent effect of methanolic extract of Cissus latifolia on mitotic index of meristematic cells of Allium cepa

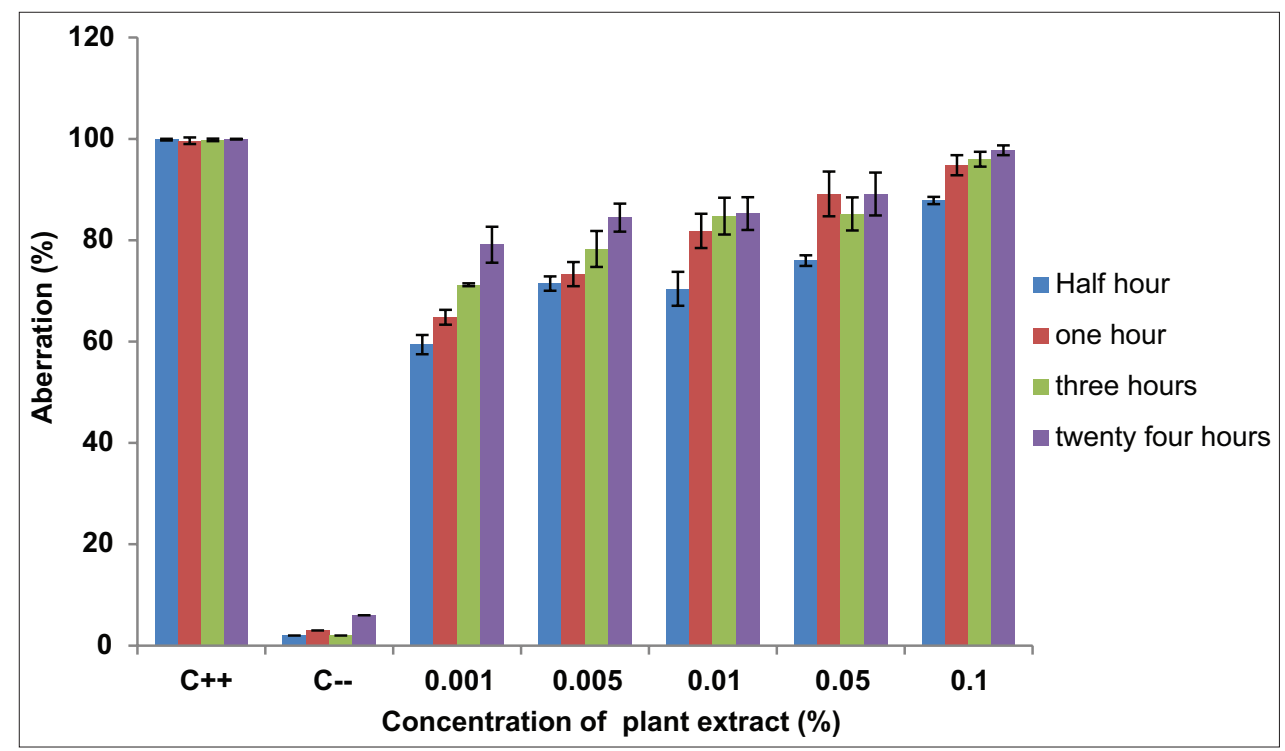

Fig. 4: Dose-dependent effect of methanolic extracts of Cissus latifolia on chromosomal aberrations in meristematic cells of Allium cepa

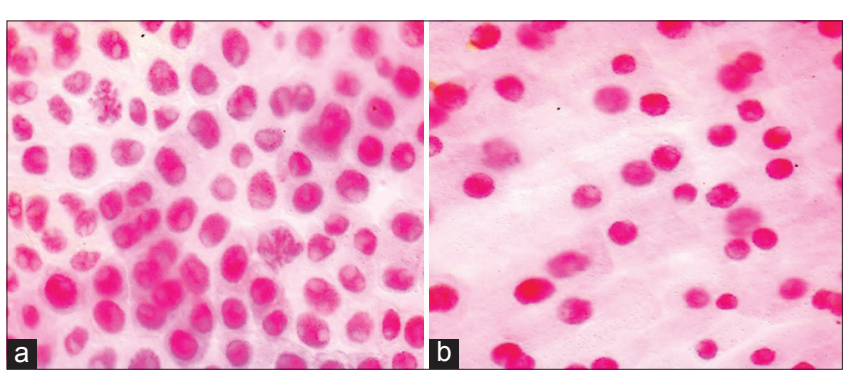

Fig. 5: (a) Nuclear lesions induced after treatment with $2 \% \mathrm{H}_{2} \mathrm{O}_{2}$; (b) modulatory action of Cissus latifolia extract showing the return of cells to normal condition after treatment
$30 \pm 2.12$ to $45.45 \pm 1.9 \%$ as compared with the other two treatments. In post-treatment, the inhibition percentage is $51 \pm 1.27-67 \pm 3.40 \%$ and $47 \pm 1.90-70 \pm 2.30 \%$ for simultaneous treatment. Hence, the post and simultaneous treatments are found to be equally effective as in pre-treatment, the extract fails to bring about a change from aberrant cells to normalcy state. In all the treatments, the concentration of the extract is dependent on the percentage of inhibition. Higher the concentration of plant extracts treated, the highest the percentage of inhibition recorded (Table 1).

A concentration-dependent higher growth rate in root was observed in the tested samples compared to control groups and showed statistical significance $(\mathrm{p}<0.05)$. Extreme retardation of root growth observed in 
the positive control $(0.50 \pm 0.34-0.38 \pm 0.34)$ revealed the cytotoxic effect of the oxidant leading to cell division inhibition and thereby improper growth. Surprisingly, very distinctive morphological alterations, namely, hooked tips, fragmented tips, swollen tips, color change in roots, and sharpness in root tips of $A$. cepa were also observed in the treated groups when compared to the control.

$$
\text { Inhibitory activity }[\%]=\frac{\mathrm{A}-\mathrm{B}}{\mathrm{A}-\mathrm{C}} \times 100
$$

Where $\mathrm{A}=$ Number of aberrant cells induced by positive control, $\mathrm{B}=$ Number of aberrant cells induced by different modes of treatment, and $\mathrm{C}=$ number of aberrant cells induced by negative control.

\section{DISCUSSION}

The present study has investigated the genotoxicity and genoprotective efficacy of methanolic $C$. latifolia extract on the $A$. cepa model system. The presence of nuclear and chromosomal aberrations confirmed the genotoxic potential of the plant. Clastogenic agents cause interphasic nuclear aberrations which can be observed as morphological alterations in the nucleus. These aberrations can be seen in the A. cepa test also as nuclear lobes, nuclear buds, micronucleus, minicells, and bi- or poly-nucleated cells [17-20]. Hence, the analysis of nuclear and chromosomal aberrations is more accurate and sensitive for investigating the impact of the test agent on the DNA [21]. According to Leme et al., 2009 [17], even though the F1 cells did not show any abnormalities, the presence of nuclear lobes and poly-nucleate cells can be a signal of cell death. The effect of trifluralin herbicide on root tips of A. cepa also showed that nuclear buds observed were the byproducts of polyploidy as it eliminates exceeding genetic material during the process [18].

According to Fenech, 2002 [22], micronucleus are formed by the incorporation of acentric fragments or some of the chromosomes during the cell cycle resulting in separation from the main nucleus. Clastogenic chemicals induce chromosomal breakages leading to fragmentation of chromosomes [23] or chromosomal bridges to form acentric fragments [24]. However, abnormal functions of mitotic spindles can trigger chromosome losses during the cell division cycle [25]. Thus, unrepaired or incompletely repaired defects in parent cells may result in the formation of micronucleus [26]. Among the nonclastogenic aberrations observed, tropokinesis might have occurred due to abnormal orientation spindle fibers [27].

Ghost cells observed in the study showed the existence of dead cells or apoptotic cells due to cytogenetic damage [28-30]. Structural chromosome aberrations form dicentric chromosomes or unequal exchange of chromatids during translocation which leads to anaphase bridges [31]. Binucleate cells observed in the study were the consequence of cytokinesis inhibition at any checkpoint of the cell cycle [32]. Incomplete cytoplasmic divisions cause giant cell formation by enlarging cell size along with DNA replication and division of nucleus [33]. The C-mitotic activity of the extract led to negligible mitotic index variations, even though the minor rise was noted in some treatment parameters [34].

$\mathrm{H}_{2} \mathrm{O}_{2}$ is used as an oxidizer in industries, disinfectant, and bleaching agent. It is relatively stable and can diffuse through the plasma membrane and enters easily to the nucleus. It will cause oxidative damages in cells by producing ROS as it reacts with the transition metals bound with DNA [35]. These will take part in lipid peroxidation by attacking the polyunsaturated fatty acids of the cell membrane leading to the loss of membrane integrity which ultimately ends up in apoptosis $[11,36]$. The ROS is detoxified by enzymatic and nonenzymatic scavenging mechanisms [37]. The main ROS scavengers in the cell are glutathione, superoxide dismutase, catalases, $\mathrm{N}$-acetyl cysteine, and provitamins [38]. The $\mathrm{H}_{2} \mathrm{O}_{2}$ has a positive impact on the levels of glutathione as it gets decreased in epidermal cells. Free radicals can make the cell more vulnerable to oxidative stress when glutathione levels in cells are depleted [39]. The plant extracts of C. latifolia equipoise this oxidative damage by acting as a genoprotective agent against $\mathrm{H}_{2} \mathrm{O}_{2}$. It has been estimated that the polyphenolic compounds present in the plants act as strong pro-oxidants that withstand the stress and modulating effects [40]. The flavonoid compounds also regulate by an indirect role in balancing the oxidative stress by inducing the expression of genes coding for antioxidant enzymes [41]

Several reports have been published so far to assess the genotoxicity of plant extracts using the A. cepa plant model. Devi and Thoppil [42] reported cytotoxicity of Orthosiphon thymiflorus in vivo in A. cepa and recorded the reduction of mitotic index and induction of chromosome aberrations in respect to time and dose-dependent effect. The extracts induced a spectrum of clastogenic as well as non-clastogenic aberrations. Evaluation of cytotoxicity and apoptotic potential of Ophiorrhiza pectinata [27] also gives the best evidence of using the plant model for preliminary assessment of toxicity studies. Leaf extract of Aglaia edulis was proved to be a source of potential bioactive compounds which found has triggered aberrations in Allium root meristem among which cytomixis was found to be the prominent one [43]. The data obtained from the study of modulatory action of the extract of Cynanchum sarcomedium on oxidative stress induced by $\mathrm{H}_{2} \mathrm{O}_{2}$ [35] further strengthens and in accordance with the findings of our study.

\section{CONCLUSIONS}

Thus present study proved that extract of C. latifolia at higher concentrations can act as potential genotoxic agents and at the same as genoprotective source against the oxidative stress induced by the $\mathrm{H}_{2} \mathrm{O}_{2}$ at lower concentrations. However, extensive studies are required to confirm the efficacy of the plant and also to dig out other therapeutic properties.

\section{ACKNOWLEDGMENT}

The first author is thankful to the University of Calicut for granting University research fellowship to complete this work. The authors are also thankful to the director of Central Sophisticated Instrumentation Facility, University of Calicut, for providing the LEICA DM6 B System Microscope and fluorescent imaging Camera LEICA DFC 450C.

\section{AUTHORS' CONTRIBUTIONS}

The first author contributed the intellectual concept, experimental design and performed laboratory experiments, data tabulation, manuscript preparation; the second author assisted in the proper correction of the manuscript to improve quality and revised to give a final outlook to the whole article.

\section{CONFLICTS OF INTEREST}

Both authors declare that there are no conflicts of interest with respect to the publication of this research article.

\section{AUTHORS' FUNDING}

Research fellowships of the University of Calicut.

\section{REFERENCES}

1. Dillard CJ, German JB. Phytochemicals: Nutraceuticals and human health. J Sci Food Agric 2000;80:1744-56.

2. Gadano AB, Gurni AA, Carballo MA. Argentine folk medicine: Genotoxic effects of chenopodiaceae family. J Ethnopharmacol 2006;103:246-51.

3. Verscheave L, Kestens V, Taylor JL, Elgorashi EE, Maes A, Van Puyvelde L, et al. Investigation of the anti-mutagenic effects of selected South African medicinal plant extracts. Toxicol In Vitro 2004;18:29-35.

4. Rao BV. Cytological effects of pendimithalin in Allium cepa root meristems. Cell Chrom Res 1989;12:57-9.

5. De-Serres FJ. Preface: Higher plants as effective monitors of 
environmental mutagens. Mutat Res 1992:270:1-3.

6. Grant WF. Higher plant assays for the detection of chromosomal aberrations and gene mutations-a brief historical background on their use for screening and monitoring environmental chemicals. Mutat Res 1999;426:107-12.

7. Fiskesjö G. The Allium test as a standard in environmental monitoring. Hereditas 1985;102:99-112.

8. Grant WF. The present status of higher plant bioassays for detection of environmental mutagens. Mutat Res 1994;310:175-85.

9. Kovalchuk O, Kovalchuk I, Arkhipov A, Telyu, P, Hohn B, Kovalchuk L. The Allium cepa chromosome aberration test reliably measures genotoxicity of soils of inhabited areas in the Ukraine contaminated by the Chernobyl accident. Mutat Res 1998;415:47-57.

10. Valko M, Rhodes CJ, Moncol J, Izakovic M, Mazur M. Free radicals, metals and antioxidants in oxidative stress-induced cancer. Chem Biol Interact 2006;160:1-40.

11. Shah K, Kumar RG, Verma S, Dubey RS. Effect of cadmium on lipid peroxidation, superoxide anion generation and activities of antioxidant enzymes in growing rice seedlings. Plant Sci 2001;161:1135-44

12. Sharma AK, Sharma A. Chromosome Techniques: Theory and Practice. New Delhi: Aditya Books; 1990.

13. Sharma S, Vig AP. Antigenotoxic effects of Indian mustard Brassica juncea [L.] Czern aqueous seeds extract against mercury [Hg] induced genotoxicity. Sci Res Essays 2012;7:1385-92.

14. Leme DM, Angelis DF, Marin-Morales MA. Action mechanisms of petroleum hydrocarbons present in waters impacted by an oil spill on the genetic material of Allium cepa root cells. Aquat Toxicol 2008;88:214-19.

15. Reshmi C, Thoppil J. Apoptotic and cytotoxic activities of strobilanthes virendrakumarana venu and p. Daniel in Allium cepa and human red blood cells. Asian J Pharm Clin Res 2019;12:93-7.

16. Akintonwa A, Awodele O, Afolayan G, Coker HA. Mutagenic screening of some commonly used medicinal plants in Nigeria. J Ethnopharmacol 2009; 125:461-70.

17. Fernandes TC, Mazzeo DE, Marin-Morales MA. Mechanism of micronuclei formation in polyploidizated cells of Allium cepa exposed to trifluralin herbicide. Pestic Biochem Phys 2007;88:252-59.

18. Migid AH, Azab YA, Ibrahim WM. Use of plant genotoxicity bioassay for the evaluation of efficiency of algal biofilters in bioremediation of toxic industrial effluent. Ecotoxicol Environ Saf 2007;66:57-64.

19. Carita R, Marin-Morales MA. Induction of chromosome aberrations in the Allium cepa test system caused by exposure of seeds to industrial effluents contaminated with azo dyes. Chemosphere 2008;72:722-25.

20. Leme DM, Marin-Morales MA. Allium cepa test in environmental monitoring: A review on its application. Mutat Res 2009;682:71-81

21. Fenech M. The in vitro micronucleos technique. Mutat Res 2002;455:81-95.

22. Yi H, Meng Z. Genotoxicity of hydrated sulfur dioxide on root tips of Allium sativum and Vicia faba. Mutat Res 2003;537:109-14.

23. Fiskesjö G. The Allium cepa test in waste water monitoring. Environ Toxicol Water Qual 1993;8:291-8.

24. Uhl M, Plewa MJ, Majer BJ, Knasmuller S. Basic principles of genetic toxicology with an emphasis on plant bioassays. In: Maluszynska J, Plewa M, editors. Bioassays in Plant Cells for Improvement of Ecosystem and Human Health: A Course Manual. Katowice: World Health Organization; 2003. p. 11-30

25. Ribeiro LR. Teste do micron ucleoemmedula ossea de roedores in vivo.
In: Ribeiro LR, Salvadori DM, Marques EK, editors. Mutagenese Ambiental. Canoas: ULBRA; 2003. p. 201-19.

26. Çelik TA, Aslantürk ÖS. Evaluation of cytotoxicity and genotoxicity of Inula viscosa leaf extracts with Allium test. J Biomed Biotechnol 2010;2010:1-8.

27. Sn PM, Thoppil JE. Evaluation of cytotoxicity and apoptotic potential of Ophiorrhiza pectinata arn. A potent anticancer agent. Asian J Pharm Clin Res 2019;12:97-102.

28. Neelamkavil SV, Thoppil JE. Toxicological evaluation of polar and nonpolar components of Isodon coetsa (Lamiaceae). Turk J Bot 2014;38:252-7

29. El-Ghamery AA, El-Nahas AI, Mansour MM. The action of atrazine herbicide as an indicator of cell division on chromosomes and nucleic acid content in root meristems of Allium cepa and Vicia faba. Cytologia 2000;65:277-87.

30. Rubeena M, Thoppil J. Cytotoxic potential of Cissus quandrangularis on Allium cepa root meristem. Int J Adv Pharm Sci 2019;10:1-6.

31. Ateeq B, Farah MA, Ali MN, Ahmad W. Clastogenicity of pentachlorophenol, 2,4-D and butachlor evaluated by Allium root tip test. Mutat Res 2002;514:105-13.

32. Prajitha V, Thoppil JE. Induction of giant cells by the synthetic food colorants viz. Lemon yellow and orange red. Cytotechnology 2014;68:1-8

33. Neelamkavil SV, Thoppil JE. C-mitotic effect of aqueous extracts of Isodon coetsa [Buch.-ham. ex D. Don] Kudo [Lamiaceae]. Nucleus 2013;56:117-22.

34. Henle ES, Linn S. Formation, prevention, and repair of DNA damage by iron/hydrogen peroxide. J Biol Chem 1997;272:19095-8.

35. Bhagyanathan NK, Thoppil JE. Genotoxic potential of cynanchum sarcomedium meve and liede coupled with its modulatory action on oxidative stress mediated genotoxicity by hydrogen peroxide. Turk $\mathrm{J}$ Biol 2016;40:120-9.

36. Apel K, Hirt H. Reactive oxygen species: Metabolism, oxidative stress, and signal transduction. Annu Rev Plant Biol 2004;55:373-99.

37. Bakkali F, Averbeck S, Averbeck D, Idaomar M. Biological effects of essential oils-a review. Food ChemToxicol 2008;46:446-75.

38. Muller M, Tausz M, Wonisch A, Grill D. Effects of an oxidizing agent [hydrogen peroxide] on the glutathione system in epidermal cells of Allium cepa L. Investigated by histochemical staining. Free Radical Res 1999;31:S121-7.

39. Rodrigues CR, Dias JH, de Mello RN, Richter MF, Picada JN, Ferraz AB. Genotoxic and anti-genotoxic properties of Baccharis trimera in mice. J Ethnopharmacol 2009;125:97-101.

40. Fitzpatrick FA. Inflammation, carcinogenesis and cancer. Int Immunopharmocol 2001;1:1651-67.

41. Kala C, Ali SS, Mohd A, Rajpoot S, Khan NA. Protection against FCA Induced oxidative stress induced DNA damage as a model of arthritis and in vitro anti-arthritic potential of Costus speciosus rhizome extract. Int J Pharmacogn Phytochem Res 2015;7:383-9.

42. Devi SE, Thoppil JE. Cytotoxic studies and phytochemical analysis of Orthosiphon thymiflorus (Roth) Sleesen. Int J Pharm Pharm Sci 2016;8:249-55.

43. Ravindran AE, Thoppil JE. Enigmatic induction of cytomixis in Allium cepa root meristem by Aglaia edulis roxb. leaf extract and its phytochemical rationale. Asian J Pharm Clin Res 2020;13:168-71. 